\title{
Effect of nano-silica on Portland cement matrix
}

\section{Efeito da nanossílica na matriz de cimento Portland}

\author{
T. M. MENDES \\ thiagomendes@utfpr.edu.b \\ https://orcid.org/0000-0002-6907-0272 \\ W. L. REPETTE b \\ wellington.repette@gmail.com \\ https://orcid.org/0000-0003-0697-2794
}

\begin{abstract}
The use of nano-particles is a current trend that may play an important role for improving the mechanical performance of Portland cement. The aim of this study is to evaluate the effect of nano-silica on Portland cement matrix. The particle size distribution of Portland cement matrix was modified by the incorporation of $11,6.2,3.1,1.7,0.85$ and $0.42 \mathrm{wt}$. $\%$ of nano-silica. The water demand and the consumption of dispersant were adjusted, and the rheological properties of suspensions were analyzed through rotational rheometry. The mechanical performance of studied mixtures was evaluated by the compressive strength. The pore size distribution was measured by mercury intrusion porosimetry (MIP), and the hydration was analyzed through X-ray diffractometry. The rheological behavior presented a considerable changed, as a consequence of high specific surface area of nano-particles. The optimum content of nano-silica, or the smaller quantity of nano-particles, that leads to the maximum strength gain, varied according to the water to solids ratio. An increasing on the hydration and a pore refinement were obtained due to the use of silica nanoparticles. The particle's packing and the pozzolanic reaction were the two main effects of nano-silica on the microstructure of Portland cement matrix.
\end{abstract}

Keywords: rheology, compressive strength, mercury intrusion porosimetry, X-ray diffraction.

\section{Resumo}

O uso de nanopartículas é uma tendência recente que pode assumir um papel importante para melhorar o desempenho mecânico do cimento Portland. O objetivo deste estudo é avaliar o efeito da nanossílica na matriz de cimento Portland. A distribuição do tamanho das partículas da matriz de cimento Portland foi modificada pela incorporação de 11, 6.2, 3.1, 1.7, 0.85 a $0.42 \%$, em massa, de nanossílica. A demanda de água e o consumo de aditivo dispersante foram ajustados, e as propriedades reológicas das suspensões foram analisadas por meio de reometria rotacional. O desempenho mecânico das misturas foi avaliado pela resistência à compressão. A distribuição do tamanho dos poros foi medida por porosimetria de intrusão de mercúrio, e a hidratação foi analisada por difratometria de raios-X. O comportamento reológico apresentou uma mudança considerável, como consequência da elevada área superficial específica das nanopartículas. O teor ótimo de nanossílica, ou a menor quantidade de nanopartículas, que leva ao maior ganho de resistência, variou de acordo com a relação água/sólidos. Um aumento na hidratação e o refinamento dos poros foram obtidos pelo uso da nanossílica. O efeito de empacotamento e a pozolanicidade são os principais efeitos da nanossílica na microestrutura da matrix de cimento Portland.

Palavras-chave: reologia, resistência à compressão, porosimetria de intrusão de mercúrio, difração de raios-X. 


\section{Introduction}

The Portland cement is widely used as a building material, with a production of more than 4.3 billions of tons in 2014 [1], albeit with the increasing environmental impacts, mainly by the emission of $\mathrm{CO}_{2}$ and the consumption of non-removable raw materials. The use of nanoparticles is a current trend, which may play an important role for an efficient using of this binder. Comparing mixtures with and without nano-silica, many researches demonstrated a gain on the compressive strength of mixtures formulated with silica nano-particles [2-8].

The improvement on mechanical properties of these materials is mainly related to the packing effect and the pozzolanic reaction of nano-silica. Ghafari et al. [3] discussed a reduction on the porosity and a pore refinement for mixtures containing nano-silica, both determined by Mercury Intrusion Porosimetry (MIP). Further, Givi et al. [4] and Haruehansapong et al. [5] published similar results for concrete containing nano-silica or nano-titanium. The above results are similar to those reported by Zhang and Li [6] for water absorption. Yu et al. [7] evaluated the pozzolanic reaction of nanosilica, considering the higher mass loss from hydrated products ( $\mathrm{CSH} / \mathrm{CAH})$, and the consumption of calcium hydroxide $\mathrm{Ca}(\mathrm{OH})_{2}$. These hydration products were measured by thermo-gravimetry. Rong et al. [8] reported similar results, investigating the reduction of calcium hydroxide peak, measured by X-ray diffraction.

The rheological behavior of suspensions was also modified due to the incorporation of silica nano-particles, presenting a considerable reduction in the workability, and in the fluidity, according to Zapata et al. [9] and Berra et al. [10]. A consequence of the increasing in the apparent yield stress and viscosity $[11,12]$, was the higher water demand of mixtures containing nano-silica, as demonstrated by Quercia et al. [13]. The aim of this research is to evaluate the effect of nano-silica on Portland cement matrix.

\section{Materials and experimental program}

A Portland cement CPV-ARI Votorantim (CPV) was employed as

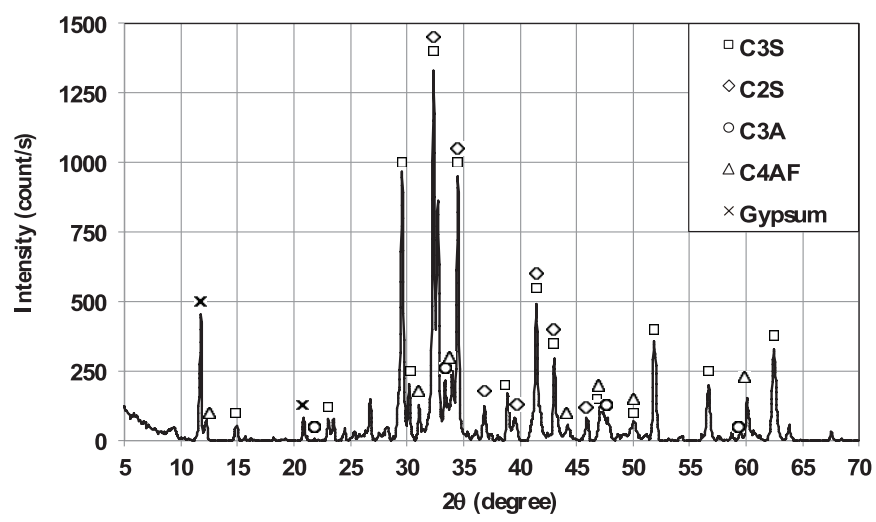

Figure 1

Portland cement diffractogram

binder, the nano-silicas CEMBINDER $8\left(\mathrm{nS}_{1}\right)$, CEMBINDER 30 $\left(\mathrm{nS}_{2}\right)$ and CEMBINDER $50\left(\mathrm{nS}_{3}\right)$ Akzo Nobel were also employed as raw materials. The chemical composition of raw materials was measured on molten samples, using fluorescence spectrometer P'ANalytical Axios Advanced. The Specific Surface Area (SSA) was measured by gas adsorption (B.E.T.) using equipment BELSORP MAX. The real density was determinated by picnometry of liquids. The Table [1] presents the physical and chemical properties of raw materials. The densities of nano-silicas $\mathrm{nS}_{1}, \mathrm{nS}_{2}$ and $\mathrm{nS}_{3}$ were calculated from density and mass concentration of suspensions: $1.4 \mathrm{~g} /$ $\mathrm{cm}^{3}$ and $50 \%, 1.10 \mathrm{~g} / \mathrm{cm}^{3}$ and $30 \%, 1.05 \mathrm{~g} / \mathrm{cm}^{3}$ and $10 \%$, respectively, resulting in 2.33, 2.25 and $2.54 \mathrm{~g} / \mathrm{cm}^{3}$. A Poly-carboxylic acid (PC) BASF ADVA 505 was employed as dispersant additive.

The Figure [1] shows the diffractogram of Portland cement CPV, which displays the phases: Alite $\left(3 \mathrm{CaO} . \mathrm{SiO}_{2}\right)$, Belite $\left(2 \mathrm{CaO} . \mathrm{SiO}_{2}\right)$, Tri-calcium aluminate $\left(3 \mathrm{CaO} \cdot \mathrm{Al}_{2} \mathrm{O}_{3}\right)$, Tetra calcium ferro-aluminate $\left(4 \mathrm{CaO} \cdot \mathrm{Al}_{2} \mathrm{O}_{3} \mathrm{Fe}_{2} \mathrm{O}_{3}\right)$, and Gypsum $\left(\mathrm{Ca} . \mathrm{SO}_{4 \cdot 1 / 2} \mathrm{H}_{2} \mathrm{O}\right)$ [14].

The particle size distribution of Portland cement was determined with a laser granulometer Malvern 2200. The particle size

Table 1

Physical and chemical properties of raw-materials

\begin{tabular}{|c|c|c|c|c|c|c|c|c|c|}
\hline Raw material & $\mathrm{SiO}_{2}$ & $\mathrm{Al}_{2} \mathrm{O}_{3}$ & $\mathrm{Fe}_{2} \mathrm{O}_{3}$ & $\mathrm{CaO}$ & $\mathrm{MgO}$ & $\mathrm{SO}_{3}$ & L.I. & $\begin{array}{c}\text { SSA } \\
\left(\mathrm{m}^{2} / \mathrm{g}\right)\end{array}$ & $\begin{array}{c}\text { Density } \\
\left(\mathrm{g} / \mathrm{cm}^{3}\right)\end{array}$ \\
\hline P. Cement (CPV) & 23.6 & 6.60 & 3.09 & 52.6 & 5.86 & 2.26 & 5.24 & 1.25 & 3.05 \\
\hline Nano-silica $1\left(\mathrm{nS}_{1}\right)$ & 99.9 & n.d. & n.d. & n.d. & n.d. & n.d. & n.d. & 47.3 & 2.33 \\
\hline Nano-silica $2\left(\mathrm{nS}_{2}\right)$ & 99.9 & n.d. & n.d. & n.d. & n.d. & n.d. & n.d. & 88.9 & 2.25 \\
\hline Nano silica $3\left(\mathrm{nS}_{3}\right)$ & 99.9 & n.d. & n.d. & n.d. & n.d. & n.d. & n.d. & 44.6 & 2.54 \\
\hline
\end{tabular}

\section{Table 2}

Composition of mixtures (wt.\%)

\begin{tabular}{ccccccc}
\hline Mixtures & $\mathbf{1 1} \mathbf{n S}$ & $\mathbf{6 . 2} \mathbf{n S}$ & $\mathbf{3 . 1 6} \mathbf{n S}$ & $\mathbf{1 . 7} \mathbf{n S}$ & $\mathbf{0 . 8 5} \mathbf{n S}$ & $\mathbf{0 . 4 2} \mathbf{n S}$ \\
\hline $\mathrm{CPV}$ & 89.00 & 93.8 & 96.84 & 98.30 & 99.15 & 99.58 \\
$\mathrm{nS}_{1}$ & 6.26 & 4.49 & 1.95 & 0.64 & 0.32 & 0.16 \\
$\mathrm{nS}_{2}$ & 2.73 & 1.32 & 0.94 & 0.80 & 0.40 & 0.20 \\
$\mathrm{nS}_{3}$ & 1.99 & 0.38 & 0.26 & 0.27 & 0.13 & 0.06 \\
$\Sigma \mathrm{nS}$ & 11.0 & 6.20 & 3.16 & 1.70 & 0.85 & 0.42 \\
\hline
\end{tabular}




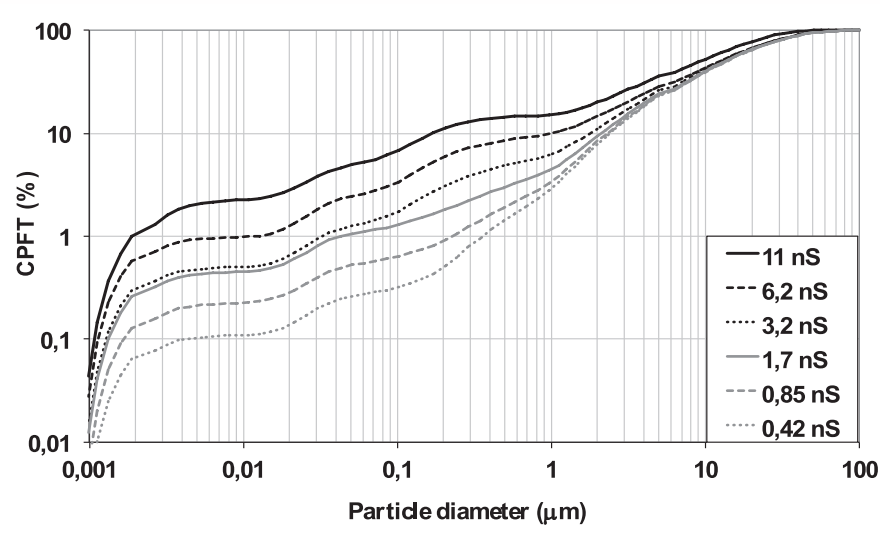

Figure 2

Particle size distribution of mixtures

distribution of nano-silicas was measured by Dynamic Laser Scattering (DLS), using Microtac Nano-Flex equipment. The particle size distributions of mixtures was adjusted by Equation $A[15,16]$ applying: $D_{L}=100 \mu \mathrm{m} ; D_{S}=0.001 \mu \mathrm{m}(1 \mathrm{~nm})$; and the distribution coefficients $q=0.37,0.50,0.55$ and 0.61 . The Table [2] exhibits the compositions of these formulations, which contain $11,6.2,3.16$ and $1.7 w t . \%$ of nano-silicas, respectively. For mixtures containing 0.85 and $0.42 w t . \%$ of nano-silicas, rates were obtained by dividing each nano-silica amount of the previous formulation by 2 . The Figure [2] presents the particle size distribution of studied mixtures.

CPFT $=\left[\frac{\left(D_{P}^{q}-D_{S}^{q}\right)}{\left(D_{L}^{q}-D_{S}^{q}\right)}\right]$

where:

CPFT - cent percent finer than (\%);

$D_{P}$ - Particle diameter $(\mu \mathrm{m})$;

$D_{S}$ - Particle diameter of smaller particle $(\mu \mathrm{m})$;

$D_{L}$ - Particle diameter of larger particle $(\mu \mathrm{m})$;

$q$ - coefficient of distribution;

The water to solids ratio $(\mathrm{w} / \mathrm{s})$ and the dispersant $(\mathrm{PC})$ content were adjusted in order to obtain a rheological behavior compatible with molding by casting. The Table [3] presents all studied formulations. The inter particle separation (IPS) were calculated from these results and are described in Table [3]. The volumetric concentration of suspensions (Vs) was calculated from water and solids contents; volumetric surface area (VSA) was calculated from product of specific surface area (SSA) and density of compositions, following Funk and Dinger [15]. The initial porosity $\left(P_{0}\right)$ was estimated applying the linear packing model developed by Yu and Standish [16] and Yu et al. [17].

The suspensions of nano-silica and the dispersant were previously diluted with deionized water. The mixing of paste was conducted in a laboratory mixer applying the following process: (i) dry powder was added to the recipient and mixed at $60 \mathrm{rpm}$ during $60 \mathrm{~s}$; (ii) $2 / 3$ of the suspension (water + dispersant + nano-silica) was added and mixed at $60 \mathrm{rpm}$ during $120 \mathrm{~s}$; (iii) $1 / 3$ of the suspension (water + dispersant + nano-silica) was mixed at $60 \mathrm{rpm}$ during $120 \mathrm{~s}$. The rheogram was measured 30 seconds after mixing, using a concentric cylinders geometry. The tests were carried for $10 \mathrm{~g}$ of paste and shear rates varied between 10 and $100 \mathrm{rpm}$. All these tests were done at $23^{\circ} \mathrm{C}$. The Bingham model was applied to calculate the apparent yield stress and viscosity of suspensions.

Height cylindrical samples $(2: 5 \mathrm{~cm})$ were molded and manually compacted in order to avoid molding defects. Samples were kept at room temperature $\left(22^{\circ} \mathrm{C}\right)$ during 24 hours, and during 18 hours immersed in water at $85^{\circ} \mathrm{C}$. The upper face of specimens was sliced, resulting in a cylindrical specimen $(2: 4 \mathrm{~cm})$. The compressive strength was measured from six specimens, applying a loading rate of $2.5 \mathrm{MPa} / \mathrm{s}$. The pore size distribution of mixtures was measured by mercury intrusion porosimetry, using a Micrometrics Pore Size equipment (contact angle = $\left.140^{\circ}\right)$. The samples were milled and sieved in a 200 mesh (75 $\mu \mathrm{m})$, the diffractogram of randomly oriented sample was obtained with a Philips MPD1880 X-ray diffractometer (Cu $40 \mathrm{kV}$ $30 \mathrm{~mA} \mathrm{Ka} 2 \theta=5-70^{\circ}-0.2 \%$ s).

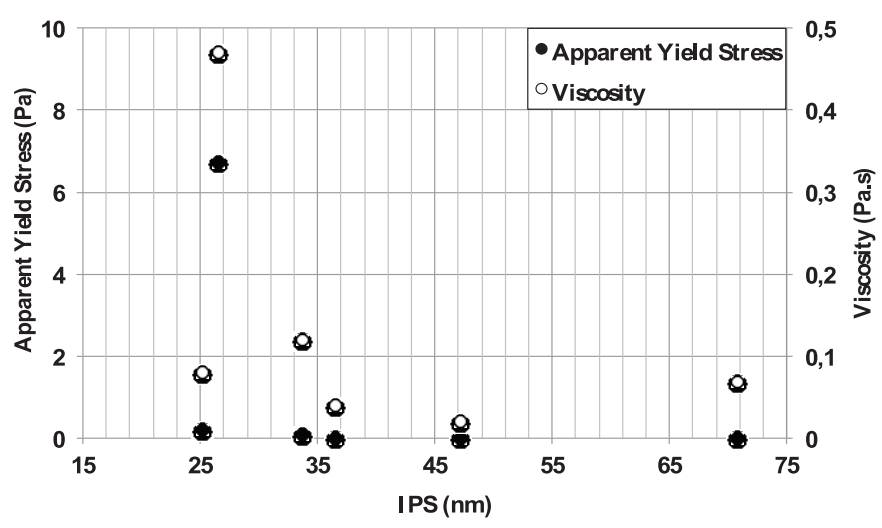

Figure 3

Effect of inter-particle separation (IPS) on rheological properties

\section{Table 3}

Composition and physical characteristics of suspensions

\begin{tabular}{|c|c|c|c|c|c|c|}
\hline Mixture & PC & $w / s$ & Vs & VSA & PO & IPS (nm) \\
\hline $11 \mathrm{nS}$ & 12.0 & 0.39 & 45.92 & 22.34 & 36.88 & 26.57 \\
\hline $6.2 \mathrm{nS}$ & 10.0 & 0.28 & 53.72 & 14.20 & 33.31 & 25.50 \\
\hline $3.16 \mathrm{nS}$ & 4.00 & 0.27 & 56.24 & 9.61 & 31.22 & 33.73 \\
\hline $1.7 \mathrm{nS}$ & 3.00 & 0.23 & 56.10 & 7.40 & 30.22 & 47.22 \\
\hline $0.85 \mathrm{nS}$ & 4.00 & 0.20 & 61.43 & 5.67 & 29.63 & 36.52 \\
\hline $0.42 \mathrm{nS}$ & 6.00 & 0.24 & 56.99 & 4.80 & 29.33 & 70.81 \\
\hline
\end{tabular}




\section{Results and discussions}

The Figure [3] shows the rheological properties of pastes formulated with Portland cement CPV and nano-silica. The suspension's yield stress presents a direct relation with the content of nano-silica or with the volumetric surface area (VSA), as seen on the Table [3]. The addition of nano-silica reduces the interparticle separation (IPS), and consequently an increasing tendency on suspension yield stress and viscosity was observed. Results are similar to those reported by Senff et al. [11] e Hou et al. [12] for mixtures containing silica nano-particles considering these same rheological properties. Flatt and Bowen [18] restricted to Van der Walls the forces for modeling the yield stress of ceramic suspensions, which is inversely proportional to the inter particle separation (1/IPS ${ }^{2}$ ). Pileggi et al. 2000 [19] presents the concept of particle crowding index $(\mathrm{PCl})$, which relates the inter-particle separation (IPS) and the diameter of particles. This index presented a direct relationship with the viscosity of ceramic suspensions.

The Figure [4] shows the compressive strength of mixtures containing Portland cement CPV and nano-silica, the adjusting of surface was obtained by linear interpolation. The effect of water/solids and content of nano-silica was plotted shows that the optimum nano-silica content varies according to the water to solids ratio. Yazdanbakhsh and Grasley [20] suggested that the theoretical maximum achievable dispersion of nanoinclusions varies according to water contend in cement pastes. Isfahani et al. [21] presented results those confirm this hypothesis, for mixtures formulated with water to binder ratio of $0.5,0.55$ and 0.65 . Published results by Mendes et al. [2] shows the same value for the optimum content of nano-silica for two different mixtures, containing 10 and $20 w t . \%$ of silica fume, but both formulated with a water/powder 0.27 . The limit of solubility of the nanosilica into the cementiteous matrix also depends on the particle size of nano-dispersions.

The Figure [5] shows the pore size distribution of mixtures formulated with Portland cement CPV and nano-silica; open porosity $\left(P_{0}\right)$ presents a reduction tendency as water/powder ratio and the content of nano-silica decreases. The capillary pores $(0,01-$ $1 \mu \mathrm{m})$ and the pores of air-entrapped bubbles (10-1000 $\mu \mathrm{m})$ are observable for all studied formulations. All mixtures presented a gapped pore size distribution. For the nanometric pores $(<$ $100 \mathrm{~nm}$ or $0,1 \mu \mathrm{m})$, mixture containing $3 w t . \%$ of nano-silica shows the finer nanometric porosity, and the size distribution of nano-pores varied according to the content of nano-silica. A modification on the pore structure at nanometric scale of Portland cement matrix was achieved. This refinement of pores for mixtures containing nano-silica indicated the combined effect of the particle packing and hydration products $(\mathrm{CSH} / \mathrm{CAH} / \mathrm{CH})$ on microstructure, mainly for pores smaller than $10 \mathrm{~nm}$ or $0,01 \mu \mathrm{m}$. The Figure [6] shows X-ray diffraction results of cement pastes containing nano-silica. For the mixture containing $3 \mathrm{wt} \%$ of nano-silica, the Alite phase $\left(\mathrm{C}_{3} \mathrm{~S}\right)$ showed the minimum value for the peak at $2 \theta=29.5^{\circ}$ [14]. Due to the hydration reaction $[7,8]$, and confirmed by the increasing on pores smaller than $10 \mathrm{~nm}$. The peak of calcium hydroxide $(\mathrm{CH})$ at $2 \theta=18.1^{\circ}$ [14], also presented a considerable intensity when compared to the initial diffractogram of Portland cement CPV, without Portlandite [14]. As a consequence of the nucleation and the pozzolanic reaction of silica nanoparticles. The calcium/silica ratio $(\mathrm{Ca} / \mathrm{Si})$ of these compositions varies from 2.0 for the mixture containing $1.7 \mathrm{wt} \%$ of nano-silica to 1.4 for the composition containing $11 \mathrm{wt} . \%$ of silica nano-particles. This variation shall modify the stoichiometric structure of calcium silicate hy-

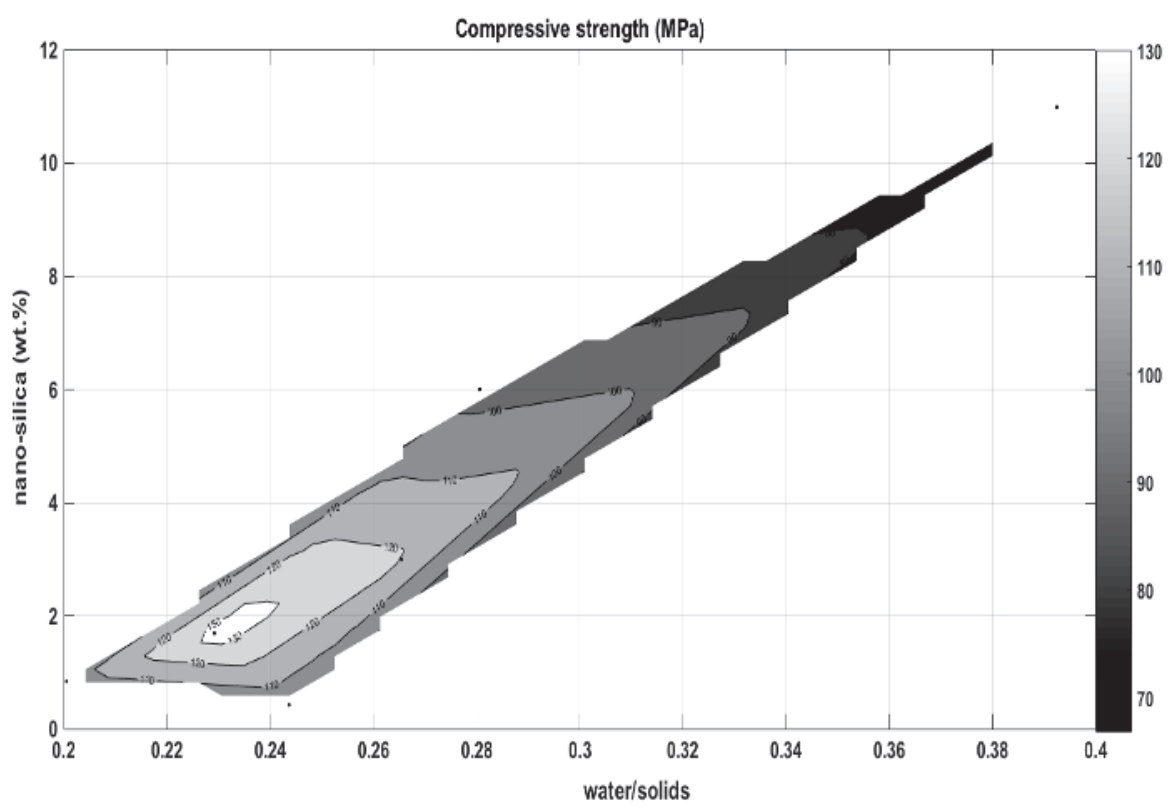

Figure 4

Effect of water/solids ratio and content of nano-silica on compressive strength 
drates (C-S-H), as demonstrated by Hara and Inoue [22] for colloidal silica and calcium hydroxide suspensions, and the consumption of calcium hydroxide from pozzolanic reaction.

\section{Conclusion}

The main effect of nano-silica on rheological behavior of Portland cement matrix is to reduce the inter-particle separation, increasing the apparent yield stress and viscosity of suspensions, due to the high specific surface area of nano-particles. As consequence, the increasing on the water demand and on the consumption of dispersant, were needed.

Considering the compressive strength of Portland cement matrix,

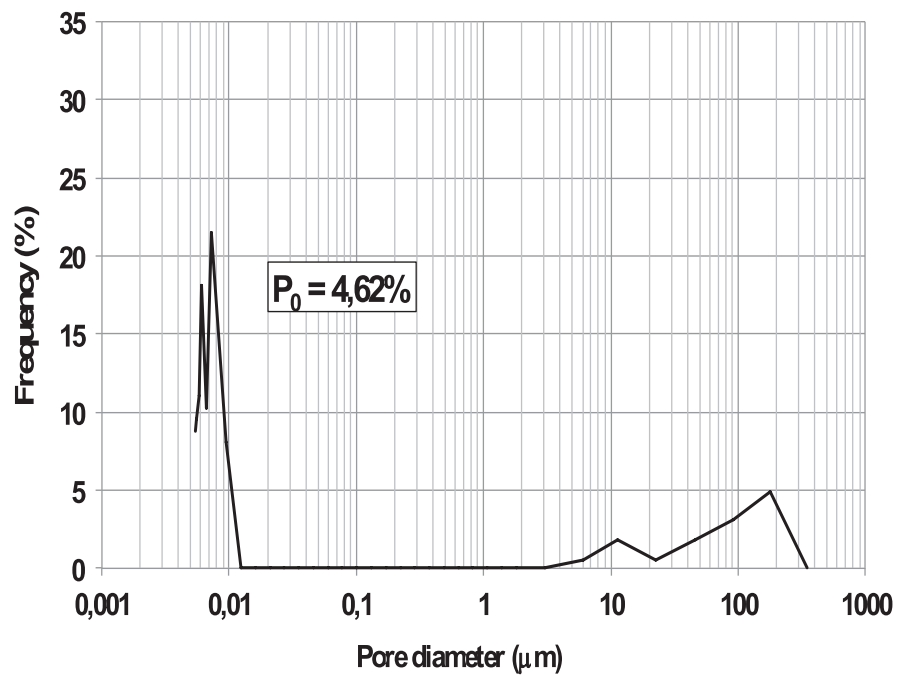

a

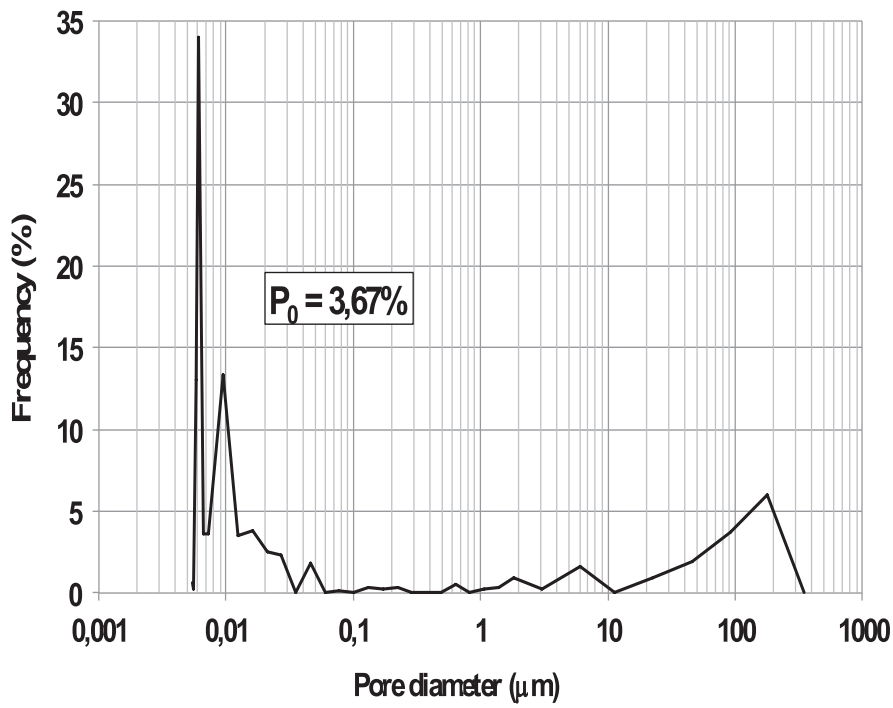

C the optimum content of nano-silica varies according to the water/ solids ratio. For large amount of nano-silica, the increasing on the water demand leads to a reduction on the compressive strength. The effects of nano-silica on the microstructure of Portland cement matrix are the increasing on the hydration reaction and the pore refinement, due to the pozzolanic reaction and packing effect of nanoparticles. Allowing the modifying of microstructure at a nanometric scale.

\section{Acknowledgements}

The authors acknowledge the Araucária Foundation and the Coordination for the Improvement of Higher Education Personnel

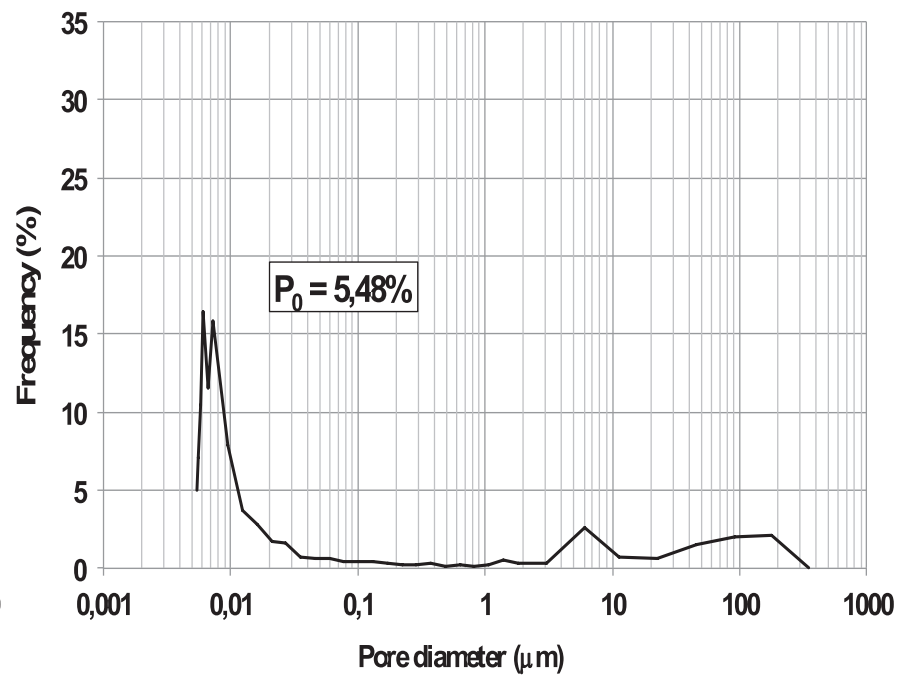

b

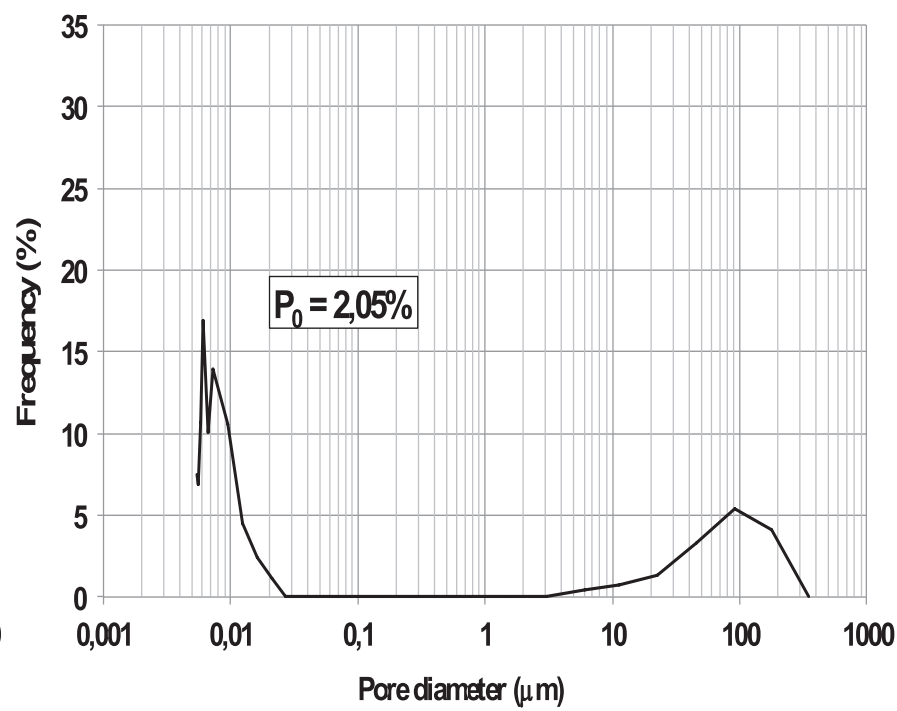

d

Figure 5

Pore size distribution and Porosity (P0) of mixtures (a) $11 \mathrm{nS}$; (b) $6 \mathrm{nS}$; (c) $3 \mathrm{nS}$; (d) $1.7 \mathrm{nS}$ 


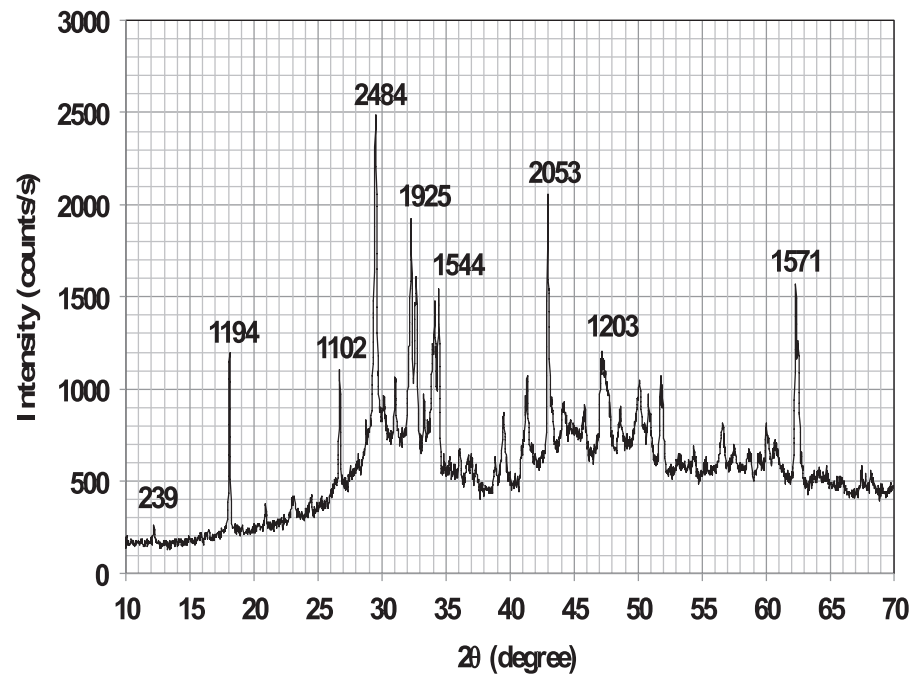

a

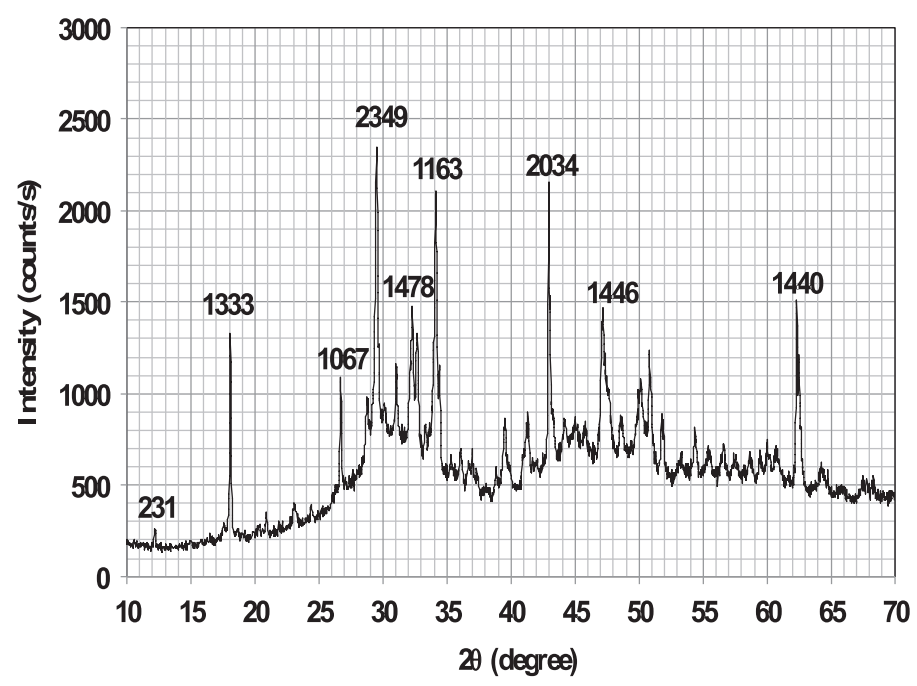

(C)

Figure 6

Diffractograms (a) $11 \mathrm{nS}$; (b) $6 \mathrm{nS}$; (c) 3 ns; (d) $1.7 \mathrm{nS}$

(CAPES). The authors also acknowledge the Microstructure Laboratory of the University of São Paulo (LME / USP), the Laboratory of Nanotechnology Applied to Building Materials (Nanotecnologia ( UFSC) and the Laboratory of Nanotechnology of the University of São Paulo (LME / USP). Applied Nuclear Physics of the State University of Londrina (LFNA / UEL).

\section{References}

[1] CEMBERAU. Activity Report. (2014). Bruxelas: s.n., 2014, $44 p$. Available at www.cemberau.org

[2] MENDES, T.M., REPETTE, W.L., P.J. REIS. Effect of nano-silica on mechanical properties and microstructure of

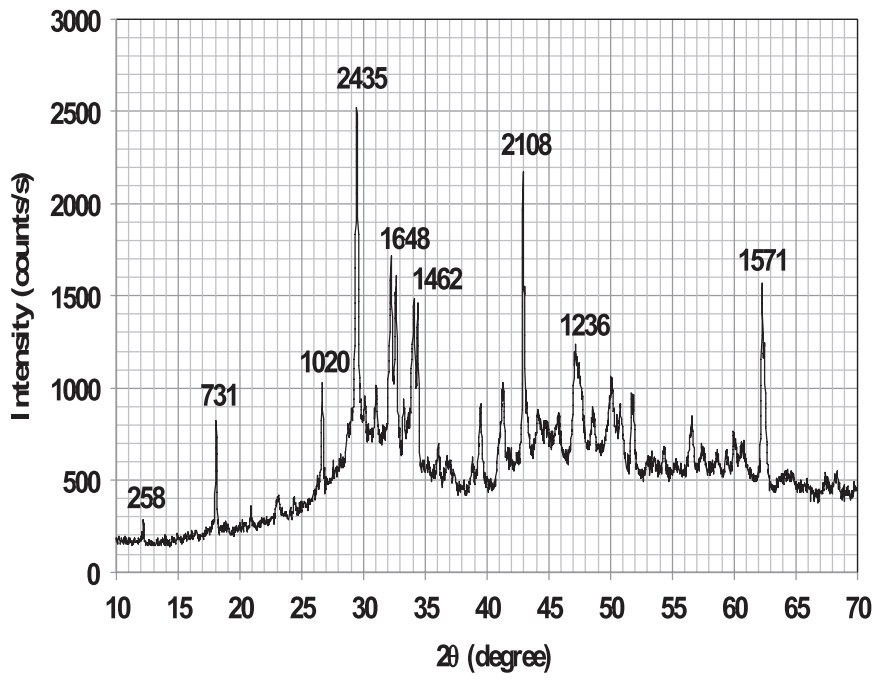

b

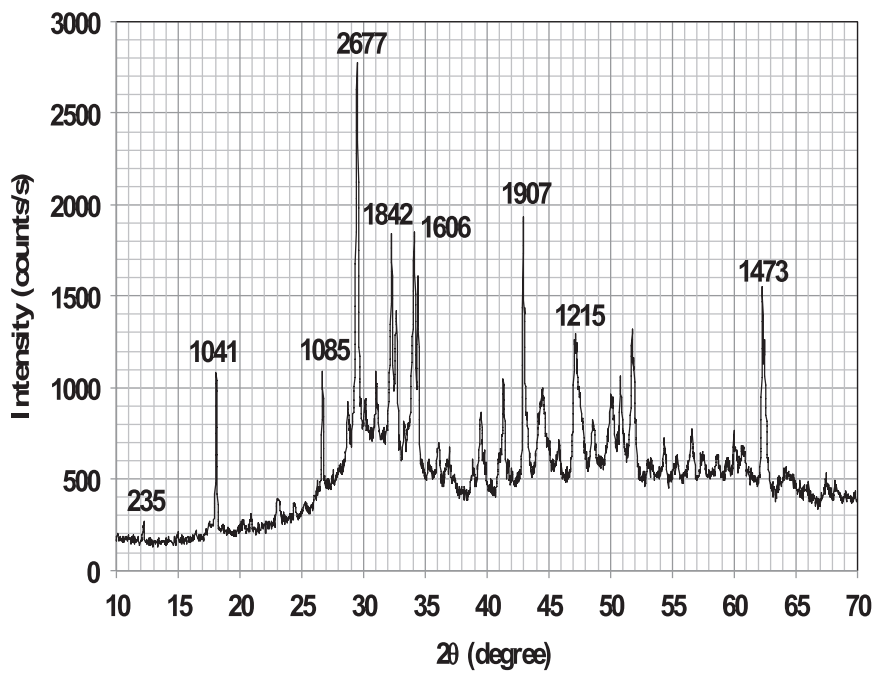

d

ultra high strength concretes. Cerâmica, v. 63, n.367, 2017, p. 387-394.

[3] GHAFARI, E., COSTA, H., JULIO, E., PORTUGAL, DURÕES A., L. The effect of nanosilica addition on flowtability, strength and transport properties of ultra high performance concrete. Materials and Design, v. 59, 2014, p. 1-9.

[4] GIVI, A., RASHID, S., AZIZ, F., SALLEH, M. The effects of lime solution on the properties of $\mathrm{SiO}_{2}$ nanoparticles binary blended concrete. Composites: Part B, v. 42, n.3, 2011, p. 562-569.

[5] HARUEHANSAPONG, S., PULNGERN, T., CHUCHEEPSAKUL, S. Effect of the particle size of nano-silica on the compressive strength and the optimum replacement content 
of cement mortar containing nano- $\mathrm{SiO}_{2}$. Construction and Building Materials, v.50, 2014, p. 471-477.

[6] ZHANG, M., LI, H. Pore structure and chloride permeability of concrete containing nano-particles for pavement. Construction and Building Materials, 2011, v.25, n.2, p 608-616.

[7] YU R., SPIESZ, P., BROUWERS, H.J.H. Effect of nanosilica on the hydration and microstructure development of Ultra-High Performance Concrete (UHPC) with a low binder amount. Construction and Building Materials, v. 65, 2014, p. $140-150$

[8] RONG, Z., SUN, W., XIAO, H., JIANG, G. Effects of nano$\mathrm{SiO}_{2}$ particles on the mechanical and micro-structural properties of ultra-high performance cementitious composites. Cement and Concrete Composites, v. 56, 2015, p. 25-31.

[9] ZAPATA, L. E., PORTELA, G., SUÁREZ, O.M., CARRASQUILO, O. Rheological performance and compressive strength of superplasticizer cementitious mixtures with mi$\mathrm{cro} /$ nano-SiO2 additions. Construction and Building Materials, v. 41, 2013, p. 708-716.

[10] BERRA, M., CARASSITI, F., MANGIALARDI, T., PAOLINI, A.E., SEBASTIANI, M. Effects of nanosilica addition on workability and compressive strength of Portland cement pastes. Construction and Building Materials, v. 35, 2012, p. 666-675.

[11] SENFF, L., LABRINCHA, J.A., FERREIRA, V.M., HOTZA, D., REPETTE W.L. Effect of nano-silica on rheology and fresh properties of cement pastes and mortars. Construction and Building Materials, v. 23, n.8, 2009, p. 2487-2491.

[12] HOU, P., KAWASHIMA, S., WANG, K., CORR, D.J., QIAN, J., SHAH, S.P. Effects of colloidal nano-silica on rheological and mechanical properties of fly ash-cement mortar. Cement and Concrete Composites, v. 35, n.1, 2013, p. 12-22.

[13] G. QUERCIA, G. HUSKEN, H.J.H. BROWERS. Water demand of amorphous nano silica and its impact on the workability of cement paste. Cement and Concrete Research, v.42, n.2, pp. 344-357, 2012.

[14] AM. SOC. TEST. MATER. "Standard method for determination of the proportion on phases of Portland cement and Portland cement clinker using powder diffraction analysis", C1365, 2011, 10p.

[15] FUNK, J.E., DINGER, D. Predictive Process Control of Crowed Particulate Suspension. Massachusetts, USA, 1994, 786p.

[16] YU, A.B., STANDISH, N. Estimation of the porosity of particle mixtures by a linear-mixture packing model. Ind. Eng. Chem. Res. v.30, n.6, 1991, p. 1372-1385.

[17] YU, A.B., FENG, C., ZOU; R., YANG, P. On the relationship between porosity and interparticle forces. Powder Technology, v.130, 2003, p. 70-76.

[18] FLATT, R.J., BOWEN, P. Yodel: A Yield Stress Model for Suspensions. Journal of American Ceramic Society, v. 89, n.4, 2006, p. 1244-1256.

[19] PILLEGI, R.G., STUDARD, A.R., PANDOFELLI, V.C. Um modelo para previsão da viscosidade mínima de suspensões cerâmicas. Cerâmica, v.46, n.299, 2000, p. 160-165.

[20] YAZDANBAKHSH, A., GRASLEY, Z. The theoretical maximum achievable dispersion of nanoinclusions in cement paste. Cement and Concrete Research, v.42, n.6, 2012, p. 798-804.

[21] ISFAHANI, F.T., RADAELLI, E., LOLLINI, F.; BERTOLINI, W., LI, L. Effects of Nanosilica on Compressive Strength and Durability Properties of Concrete with Different Water to Binder Ratios. Advances in Materials Science and Engineering, 2016. http://dx.doi.org/10.1155/2016/8453567.

[22] HARA, N., INOUE, N. Formation of jennite from fumed silica. Cement and Concrete Research, v.10, 1980, p. 677-682. 